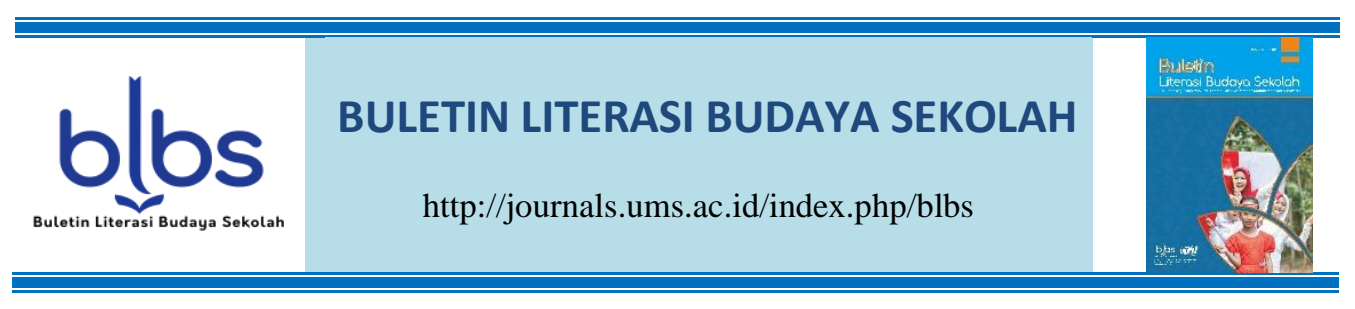

\title{
PENGUATAN PENDIDIKAN KARAKTER DI SEKOLAH MELALUI PERAN GURU SEBAGAI FASILITATOR SISWA UNTUK MENINGKATKAN KOMPETENSI SIKAP SISWA
}

\author{
Ika Indah Pratiwi ${ }^{1}$, Indah Suryati ${ }^{2}$, Aji Nur Cahyo ${ }^{3}$, \\ Felix Indra Setiaputra ${ }^{4}$ \\ 1,2,3,4 Universitas Muhammadiyah Surakarta \\ Universitas Muhammadiyah Surakarta, Surakarta, Indonesia \\ Email: ikaindah593@gmail.com, Indahsuryati12@gmail.com, ajinurc52@gmail.com, \\ Felixsetiaputra74@gmail.com
}

\begin{tabular}{|c|c|}
\hline \multicolumn{2}{|c|}{$\begin{array}{l}\text { Submitted: 2020-08-19 } \\
\text { Accepted: 2020-09-09 } \\
\text { Published: 2020-12-07 }\end{array}$} \\
\hline Keywords: & Abstract \\
\hline $\begin{array}{l}\text { Character } \\
\text { Education } \\
\text { Teacher Role } \\
\text { Student } \\
\text { Outcomes }\end{array}$ & $\begin{array}{l}\text { Character education is the main program that must be in school. This } \\
\text { study aims to evaluate evaluatively the strategy and implementation } \\
\text { of character education by the teacher as a facilitator in improving the } \\
\text { competence of students' attitudes at SMP Muhammadiyah } 4 \text { Sambi, } \\
\text { Boyolali. In this study using qualitative research methods through } \\
\text { descriptive explanations that use interviews, documentation, and } \\
\text { direct observation related to the teacher's efforts when doing } \\
\text { classroom learning and strengthening character education through } \\
\text { school programs and in their responsibilities as educators. Research } \\
\text { at SMP Muhammadiyah } 4 \text { Sambi, Boyolali shows that teachers have } \\
\text { an important role in educating students, especially regarding } \\
\text { character education because the character of students is an important } \\
\text { part of educational outcomes, because education is not only about } \\
\text { grades and academic results, but what is more important is character. } \\
\text { which is in students to apply their knowledge in everyday life so that } \\
\text { students can have good quality academics and be applied in all areas } \\
\text { of community life and become good citizens. }\end{array}$ \\
\hline
\end{tabular}

\section{PENDAHULUAN}

Pendidikan karakter merupakan suatu hal yang sangat penting untuk diterapkan dalam lingkungan keluarga, dan masyarakat serta yang tidak kalah penting perlu diterapkan dalam sekolah. Penguatan pendidikan karakter sangat penting dilakukan dan diterapkan dalam sekolah-sekolah karena menurut pandangan Muhadjir Effendy (2016 bangsa dapat dikatakan bangsa yang besar jika pendidikan dapat menerapkan pendidikan karakter sehingga karakter peserta didik menjadi kuat serta karakter baik tersebut dapat diterapkan dengan pengetahuan dan kompetensi yang dimiliki peserta didik dalam proses belajarnya.

Karakter yang ada di setiap peserta didik berbeda-beda karena menurut psikologi pendidikan, setiap manusia memiliki pertumbuhan dan perkembangan 
yang berbeda sehingga tidak dapat menerapkan pendidikan karakter yang sama, sehingga dalam penguatan pendidikan karakter diperlukan sebuah susunan program yang mencakup seluruh kompetensi sikap siswa dan tidak terlepas dari usaha pendidik sebagai fasilitator siswa. Dan di dalam karakter-karakter yang berbeda-beda tersebut, maka dalam konsep dan pedoman penguatan pendidikan karakter mengacu pada beberapa rangkaian sikap yang terdiri dari sikap peserta didik, perilaku atau tingkah laku, dan juga motivasi dan olah keterampilan dari peserta didik, dengan nilai-nilai sikap itu diharapkan para peserta didik dapat menghadapi berbagai tantangan dan hambatan yang ada di abad ke-21.

Di Indonesia, pendidikan karakter sudah dimasukkan ke dalam kurikulum 2013 karena pendidikan berbasis karakter sangat diperlukan di abad ke-21 karena memiliki tujuan untuk meningkatkan proses pembelajaran sehingga peserta didik memperoleh pengetahuan dan mengetahui bagaimana pengetahuan tersebut digunakan dalam sehari-hari secara bertanggung-jawab dan pendidikan berbasis karakter ini juga meningkatkan kompetensi sikap, jika para peserta didik mempunyai kompetensi pengetahuan dan kompetensi sikap yang baik, maka kompetensi tersebut dapat membantu kehidupan peserta didik untuk menghadapi tantangan di abad ke-21. Oleh karena itu, pendidikan karakter sudah menjadi pembahasan yang sentral di pendidikan dan sudah diterapkan dan dikembangkan di setiap proses pendidikan di Indonesia.

Dalam pendidikan yang berbasis karakter, upaya yang paling efektif adalah menggunakan kompetensi pada guru, karena pendidikan yang diperoleh guru di dalamnya terdapat psikologi pendidikan, teori pendidikan, dan mempelajari berbagai hal mengenai pembelajaran dari dasar, tujuan, metode,media, alat dan evaluasi pendidikan. Oleh karena itu, usaha atau upaya yang dilakukan oleh guru sangat diperlukan karena guru memberi fasilitas peserta didik untuk tumbuh dan berkembang, menemukan ilmu yang akan digunakan dalam kehidupan, dan yang terpenting mendidik peserta didik untuk menjadi manusia yang beriman dan bertakwa kepada Tuhan Yang Maha Esa dan memiliki jiwa sosial yang baik dan berakhlak mulia serta dapat menyeimbangkan pengetahuannya untuk diaplikasikan di kehidupannya. Melalui hal-hal itu, guru dapat memberi contoh perilaku dari keteladanan dan pembiasan kepada peserta didiknya. Guru memiliki tanggung jawab untuk memberi peserta didik dorongan, motivasi, panduan dan meningkatkan rangsangan anak untuk meningkatkan proses pembelajaran dan hasil evaluasi pendidikan di Indonesia.

Di dalam usaha guru untuk melakukan pendidikan karakter diperlukan hubungan antara guru dan peserta didik karena guru memiliki peran untuk dapat memberi pengaruh nilai-nilai baik kepada peserta didik, jika hubungan guru dengan para peserta didik dapat terjalin dengan baik, maka guru dapat masuk dalam kehidupannya sehingga guru mengetahui pembelajaran karakter yang relevan sesuai dengan keadaan psikologis anak. Guru perlu melakukan perbaikan pada karakter anak karena anak adalah penerus bangsa dan guru membawa tanggung jawab untuk mendidik untuk menjadi warga negara yang baik baik dalam hal pengetahuan, dan sikap serta keterampilan.

Kurikulum 2013 menyebutkan bahwa ada dua kompetensi sikap yang harus ada dalam pendidikan karakter, yaitu kompetensi sikap spiritual yang di dalamnya terdapat usaha pendidikan karakter untuk meningkatkan iman dan takwa kepada 
Ika Indah Pratiwi ${ }^{1}$, Indah Suryati ${ }^{2}$, Aji Nur Cahyo ${ }^{3}$, Felix Indra Setiaputra ${ }^{4}$, Penguatan Pendidikan Karakter

Tuhan Yang Maha Esa, dan kompetensi sikap Sosial yang mencakup sikap-sikap sosial seperti gotong royong, tanggung-jawab, nasionalis, dll.

\section{METODE}

Dalam penelitian ini menggunakan metode penelitian kualitatif melalui penjelasan deskriptif yang merupakan penelitian dengan menghasilkan data-data deskriptif dari subyek dan informan serta setting penelitian yang ada di SMP Muhammadiyah 4 Sambi, Boyolali dan waktunya adalah pada 28 Januari-10 Februari 2020. Teknik penelitian ini menggunakan wawancara, dokumentasi, pengamatan secara langsung kepada guru ketika mengajar pembelajaran dan melakukan penguatan pendidikan karakter, baik dalam kegiatan intrakurikuler maupun kegiatan kokurikuler dan ekstrakurikuler di sekolah.

Untuk pengumpulan data pada penelitian ini, peneliti menggunakan hasil wawancara, pengamatan dan dokumentasi. Wawancara digunakan untuk mencari data atau informasi yang berkaitan dengan pelaksanaan penguatan pendidikan karakter di sekolah, beserta hambatan-hambatan dan proses pelaksanaannya serta hasil yang terlihat dalam diri siswa sekolah. Subyek wawancara dilakukan pada Ibu Umi Solikhah, S.Pd., Ibu Dian S. Kurniawati, dan Ibu Wara Suharyani, S.Pd. Wawancara difokuskan pada strategi dan implementasi pendidikan karakter dan upaya guru dalam melakukan penguatan-penguatan pendidikan yang berbasis karakter di SMP Muhammadiyah 4 Sambi, Boyolali. Pengumpulan data dari wawancara tersebut dilengkapi dengan menggunakan pengamatan langsung pada implementasi pendidikan karakter di kelas pada saat pembelajaran dan pada saat kegiatan intrakurikuler, kokurikuler dan ekstrakurikuler. Dokumentasi juga digunakan untuk melengkapi data-data tertulis dari penelitian ini dan dokumentasi dilakukan pada seluruh kegiatan sekolah selama 10 hari pada saat Pengenalan Lingkungan Persekolahan (PLP) 1 di SMP Muhammadiyah 4 Sambi. Bentuk metode yang dilakukan pada penelitian ini difokuskan untuk membahas penguatan pendidikan karakter yang dilakukan oleh guru dalam meningkatkan kompetensi siswa.

\section{HASIL DAN PEMBAHASAN}

Penelitian ini dilakukan di SMP Muhammadiyah 4 Sambi, Boyolali. Pendidikan karakter harus diimplementasikan kemudian diintegrasikan dalam kehidupan sekolah, baik dalam konteks pembelajaran di dalam kelas maupun di luar kelas. Maka, penelitian ini dimaksudkan untuk mengidentifikasi strategi dan implementasi pelaksanaan pendidikan karakter di SMP Muhammadiyah 4 Sambi. Penelitian ini difokuskan untuk membahas upaya guru sebagai fasilitator siswa untuk meningkatkan kompetensi sikap, baik kompetensi sikap spiritual maupun sikap sosial.

Pendidikan karakter dapat diimplemetasikan melalui beberapa strategi dan pendekatan yang meliputi: (1) pengintegrasian nilai dan etika pada mata pelajaran; (2) pembiasaan sholat dhuha; (3) kegiatan BTA; (4) dll. Wawancara dilakukan terhadap tiga orang guru yaitu ibu Umi Sholikhah S.Pd., ibu Dian S. Kurniawati, dan ibu Wara Suharyani, S.Pd.

Menurut wawancara dengan ibu Umi Sholikhah selaku kepala sekolah dan guru mengatakan "Pendidikan karakter dilakukan oleh semua guru, penilaian 
kurikulum 2013 terdapat penilaian pendidikan karakter. Karakter siswa di SMP Muhammmadiyah 4 Sambi berbeda-beda, ada yang karakternya sudah baik ada juga yang belum baik. Karakter yang belum baik contohnya dalam berbicara mereka terkadang masih berkata kotor. Pernah ada suatu kasus yaitu ada seorang anak yang membuat grup WhatsApp yang membagikan video porno. Setelah diberi peringatan beberapa kali siswa tersebut masih tidak mau mengakui kesalahannya. Sehingga sekolah memutuskan untuk mengembalikkan siswa tersebut kepada orang tuanya. Salah satu strategi yang digunakan untuk mendidik karakter siswa disini adalah dengan membiasakan melaksanakan sholat dhuha dan mendoakan kedua orang tua di pagi hari setiap hari selasa sampai sabtu. Pembiasaan ini bertujuan untuk membiasakan para siswa untuk disiplin dalam sholat dan menanamkan nilai keagamaan. Strategi kedua yaitu membimbing mereka untuk berpakaian dengan tertib sesuai aturan, berbicara dengan sopan. Pendidikan karakter seperti ini tidak dapat dirasakan perubahannya hanya dalam waktu yang singkat. Perubahan karakter seperti ini baru dapat dirasakan ketika mereka sudah lulus dari sekolah ini atau dalam waktu yang lama. Sebenarnya pendidkan karakter lebih penting dari pada prestasi akademik. Karena suatu saat anak anak akan berinterakasi kepada masyarakat dimana dalam suatu masyarakat nilai akademik itu tidak terlalu berpengaruh. Tetapi tidak sedikit orang tua yang menuntut nilai prestasi siswa yang baik."

Menurut wawancara dengan ibu Dian S., bependapat bahwa "Pendidikan karakter adalah pendidikan yang menitikberatkan pada sikap anak, yaitu tanggung jawab, gotong royong dan tidak menyangkut pengetahuan. Sekarang anak sulit untuk menghargai orang yang lebih tua seperti orang tua dan guru. Contohnya ketika melihat guru anak sekarang tidak mau berjabat tangan dan tegur sapa, padahal hal-hal seperti itu harus ditanamkan sejak kecil. Sebenarnya penanaman pendidikan karakter seperti ini di SMP itu sudah sangat sulit karena tidak dibiasakan sejak kecil. Anak anak disini pada awalnya masih mudah untuk di didik karakternya tetapi seiring berjalannya waktu mereka sudah terpengaruh dengan temantemannya sehingga sulit untuk di didik. Anak-anak disini kebanyakan berasal dari keluarga yang broken home dan juga kebanyakan orang tua mereka bekerja di pabrik sehingga mereka merasa kurangnya perhatian dari orang tua maka mereka susah untuk dididik. Ditambah lagi kurangnya guru di SMP Muhammadiyah 4 Sambi ini. Disini gurunya hanya sedikit dan juga kebanyakan gurunya adalah perempuan, yang menyebabkan para guru kuwalahan untuk mendidik anak disini. Mendidik anak dengan tegas namun tidak melyukai fisiknya, sebenarnya guru tidak membenci siswa tetapi hanya membenci perilakunya. Pendidikan karakter sangat penting, hasil pendidikan karakter tidak dapat dilihat dalam jangka pendek, namun dilihat dalam jagka panjang, kurang lebih 10 tahun lagi jadi pada tahun 2010 keatas, sekolah lebih mementingkan pendidikan karakter dari pada ilmu pengetahuan. Contohnya banyak siswa pintar yang mengikuti OSN tapi akhlaknya belum baik. Ada yang bunuh diri karena memiliki masalah dengan temannya. Orang pintar belum tentu dapat bersosialisasi dengan baik, kebanyakan dari mereka individualisme, oleh karena itu pendidikan harus diterapkan mulai dari sekarang. Siswa dituntut untuk peka terhadap lingkungan, contohnya ketika siswa melihat guru dalam kesulitan membawa barang maka siswa harus membantu membawakannya. Menurut mas Nadim kelulusan parameternya tidak dilihat dari nilai UN, tapi akhlak 
nomer satu. Akhlak lebih utama dari pada pengetahuan. Jika siswa memiliki moral yang bagus, maka yang lain juga bagus. Disiplin, gotong royong, pengertian, jujur itu semua bagus, tapi tidak memiliki moral yang bagus, mungkin dampaknya akan terjadi saat memiliki jabatan."

Menurut wawancara dengan Ibu Wara Suharyani, S.Pd., berpendapat bahwa "Menurut Bu Wara, cara menangani karakter siswa dengan pendekatan kepada siswa, menanyakan hal yang menjadi sumber permasalahannya. Karena siswa melakukan sesuatu pasti ada penyebabnya, siswa kesal atau memang perilakunya seperti itu untuk melampiaskan kekesalannya. Membimbing anak harus mengetahui latar belakangnya, terutama keluarganya. Membiasakan anak tertib aturan sekolah, tata karma kepada orang lain (guru, orang tua, teman), menuruti perintah yang baik, selanjutnya membiasakan untuk sholat dhuha, dzuhur, membiasakan anak berdoa, tilawah agar karakter anak menjadi lebih baik. Setelah diterapkan pendidikan karakter dan terbiasa dengan hal-hal baik, maka akan terjadi perubahan. Ada yang langsung totalitas berubah, ada yang setelah berubah kembali lagi. Melakukan home visit ke keluarganya untuk mengetahui kondisi keluarganya. Dengan membiasakan rajin sholat, tata tertib disekolah, maka akan terbawa ketika dirumah. Saat siswa sendiri dirumah terkadang tidak ada yang memantau kegiatan mereka. Rata-rata kondisi ekonomi mereka kelas menengah kebawah, dan orang tua yang bekerja sebagai buruh pabrik sering berangkat petang pulang petang. Siwa butuh kasih sayang dari orang tua, terkadang siswa mencari perhatian guru. Rata-rata siswa diperingatkan dengan tegas tidak mau, kalau diperingatkan halus, membantah. Guru-guru tidak berkecil hati, mereka berkeyakinan kalau suatu saat siswa akan berubah. Yang terpenting mereka selalu mengingatkan, dan membimbing siswa. Pada kurikulum 2013, pembiasaan pendidikan karakter memang sudah ada. Contohnya, setiap mengawali pembelajaran, diawali dengan salam, menyapa mereka, membiasakan mengabsen temannya yang tidak masuk. Merupakan nilai akhlak dan karakter kepedulian terhadap sosial. Kegiatan sholat dhuha di smp muhammadiyah 04 sambi sebelum pergantian kepala sekolah, sudah dilakukan pada jam istirahat pertama, tetapi kenyataannya siswa yang memiliki agama baik, akan melaksanakan. Siswa yang kurang perhatian dan pengawasan dirumah, akan mencari alasan agar tidak melaksanakan sholat dhuha. Maka sekarang diadakan saat awal pembelajaran, walaupun mengurangi waktu pembelajaran. Secara tidak langsung semua mata pembelajaran terdapat pendidikan karakter. Dengan pembiasaan, ketika ada kesalahan harus diperingatkan. Diawali dengan berdoa, mengucapkan salam setidaknya, termasuk pendidikan karakter. Bertanggung jawab mengerjakan tugas dan pekerjaan rumah. Pendidikan karakter tidak dibebankan kepada guru BP atau agama, tetapi semua guru. Contohnya ketika mengajar, ada yang menyontek atau tidak. Semua guru apakah dapat menerapkannya atau tidak, tapi pendidikan karakter lebih diterapkan pada pendidikan agama dan PKn."

Berdasarkan beberapa wawancara di atas, guru di SMP Muhammadiyah 4 Sambi sudah berupaya melaksanakan pendidikan karakter dengan memaksimalkan peran guru dalam program sekolah.

Terdapat lima nilai utama dalam pendidikan karakter yang harus ditanamkan pada siswa (Berdasarkan Konsep dan Pedoman Penguatan Pendidikan Karakter), yaitu sebagai berikut: 


\section{Religius}

Nilai religious atau nilai agama merupakan keimanan terhadap Tuhan Yang Maha Esa yang berupa perilaku dalam ajaran islam dan kepercayaan yang dianut, nilai agama sangat penting, pendidikan karakter siswa akan baik ketika nilai agama sudah terlaksanakan.

\section{Nasionalis}

Nilai karakter nasionalis merupakan kesetiaan, kepedulian, dan penghargaan yang tinggi terhadap bahasa, sebagai rakyat indonesia yang bertempat tinggal di indonesia tentunya kita wajib mengutamakan nasionalis. Saat pendidikan karakter baik, tetapi tidak memiliki sifat nasionalis siswa akan

\section{Mandiri}

Nilai karakter mandiri harus diterapkan kepada siswa, pendidikan karakter tidak akan tumbuh, ketika tidak ada kemauan dalam diri siswa. Dengan motivasi yang diberikan, akan mewujudkan semangat untuk menanamkan pendidikan karakter pada dirinya.

\section{Gotong Royong}

Nilai gotong royong adalah tindakan menghargai, semangat kerja sama dan bahu membahu, gotong royong yang dimaksud lebih menekankan pada sikap menolong sesama siswa untuk memperbaiki prilakunya.

\section{Integritas}

Nilai karakter integritas adalah upaya menjadikan dirinya sebagai orang yang selalu dapat dipercaya dalam perkataan, tindakan. Nilai integritas akan muncul ketika ke empat nilai sebelumnya sudah terwujud. Di dalam penguatan pendidikan karakter yang ada di SMP Muhammadiyah 4 Sambi, Boyolali menggunakan program-program pendidikan berbasis karakter yang dimasukkan ke dalam jadwaljadwal kegiatan dalam 1 minggu, untuk jadwal kegiatan pendidikan karakter di SMP Muhammadiyah 4 Sambi, Boyolali sebagai berikut:

\begin{tabular}{|l|l|l|l|l|}
\hline Hari & $\begin{array}{l}\text { Kegiatan } \\
\text { intrakurikuler }\end{array}$ & $\begin{array}{l}\text { Kegiatan } \\
\text { kokurikuler }\end{array}$ & $\begin{array}{l}\text { Kegiatan } \\
\text { ekstrakurikuler }\end{array}$ & $\begin{array}{l}\text { Nilai } \\
\text { Karakter }\end{array}$ \\
\hline Senin & $\begin{array}{l}\text { Upacara } \\
\text { (Pembiasaan), } \\
\text { Kegiatan belajar }\end{array}$ & - & - & $\begin{array}{l}\text { Religius, } \\
\text { nasionalis, } \\
\text { integritas, } \\
\text { mandiri }\end{array}$ \\
\hline Selasa & $\begin{array}{l}\text { Sholat dhuha, } \\
\text { doa, tadarus } \\
\text { juz'amma, } \\
\text { Kegiatan belajar } \\
\text { mengajar }\end{array}$ & - & BTA & $\begin{array}{l}\text { Religius, } \\
\text { integritas, } \\
\text { mandiri }\end{array}$ \\
\hline Rabu & $\begin{array}{l}\text { Sholat dhuha, } \\
\text { doa, tadarus } \\
\text { juz'amma, } \\
\text { Kegiatan belajar } \\
\text { mengajar }\end{array}$ & - & BTA & $\begin{array}{l}\text { Religius, } \\
\text { integritas, } \\
\text { mandiri }\end{array}$ \\
\hline
\end{tabular}


Ika Indah Pratiwi ${ }^{1}$, Indah Suryati ${ }^{2}$, Aji Nur Cahyo ${ }^{3}$, Felix Indra Setiaputra ${ }^{4}$, Penguatan Pendidikan Karakter

\begin{tabular}{|l|l|l|l|l|}
\hline Kamis & $\begin{array}{l}\text { Sholat dhuha, } \\
\text { doa, tadarus } \\
\text { juz'amma, } \\
\text { Kegiatan belajar } \\
\text { mengajar }\end{array}$ & -5 BTA & $\begin{array}{l}\text { Religius, } \\
\text { integritas, } \\
\text { mandiri }\end{array}$ \\
\hline Jumat & $\begin{array}{l}\text { Sholat dhuha, } \\
\text { doa, tadarus } \\
\text { juz'amma, } \\
\text { Kegiatan belajar } \\
\text { mengajar }\end{array}$ & $\begin{array}{l}\text { Hizbul Wathan } \\
\text { Sabtu }\end{array}$ & $\begin{array}{l}\text { Sholat dhuha, Les } \\
\text { doa, tadarus } \\
\text { juz'amma, } \\
\text { Kegiatan belajar } \\
\text { mengajar }\end{array}$ & $\begin{array}{l}\text { Religius, } \\
\text { integritas, } \\
\text { mandiri, } \\
\text { gotong } \\
\text { royong }\end{array}$ \\
\hline
\end{tabular}

\section{Kegiatan Sholat Dhuha}

Kegiatan yang dilakukan setiap pagi kecuali hari senin, mencerminkan nilai religius

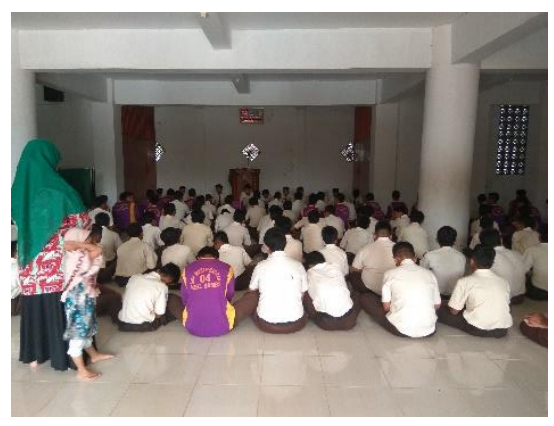

\section{Upacara}

Kegiatan upacara yang dilakukan dihari senin, mencerminkan nilai nasionalisme. Bukan hanya nilai nasionalisme, tetapi kerapian ketertiban juga tercerminkan saat kegiatan upacara.

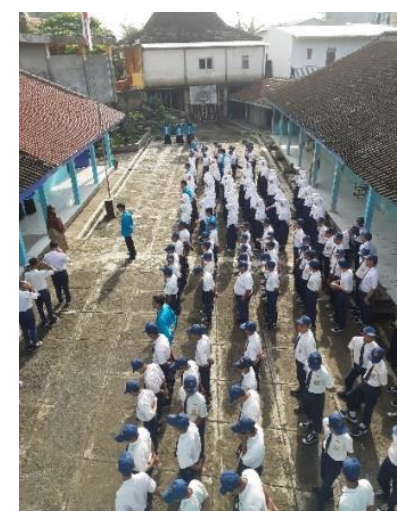

Hizbul Wathan 
Kegiatan hizbul wathan yang dilakukan pada hari jumat, mencerminkan nilai gotong royong. Dalam kegiatan hizbul wathan siswa diajarkan untuk saling membantu, menerapkan kedisiplinan, kerapian, kejujuran.

\section{Pembelajaran Matematika}

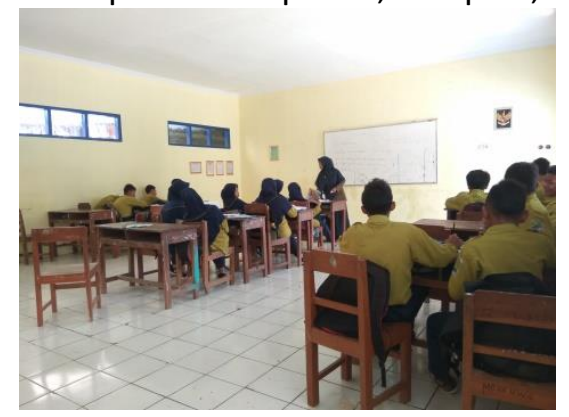

Dalam kegiatan pembelajaran siswa diuji keaktifannya, nilai mandiri dan integritas sangat tercerminkan. Di SMP Muhammadiyah 4 Sambi, pendidikan karakter tidak hanya terfokus pada mata pelajaran PKn dan agama, tetapi semua guru harus menerapkannya di dalam kelas.

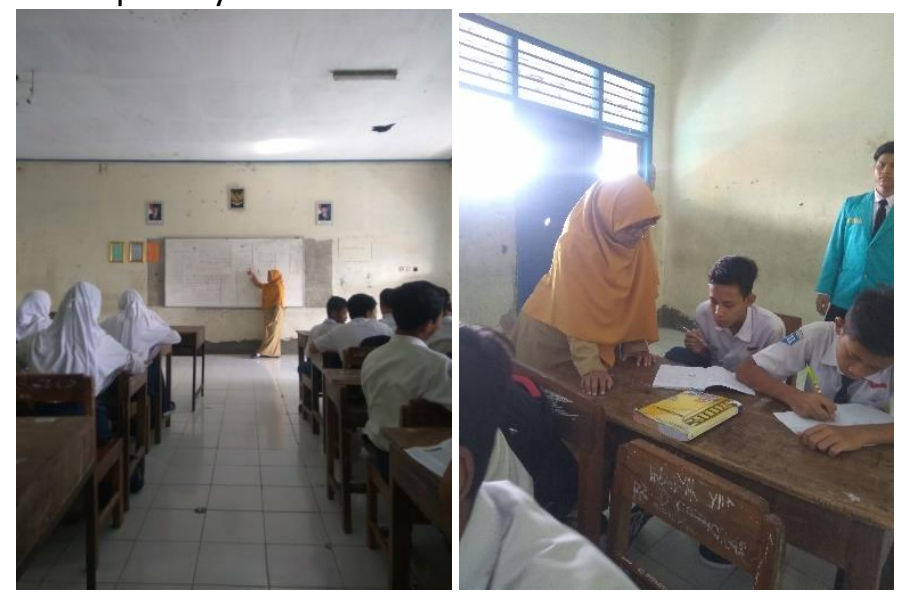

Terlihat dari jadwal kegiatan, SMP Muhammadiyah 4 Sambi sudah menerapkan ke-5 nilai utama pendidikan karakter yang harus diterapkan pada siswa.

SMP Muhammadiyah 4 Sambi, Boyolali menggunakan perencanaan dalam Kegiatan Belajar Mengajar (KBM) di kegiatan intrakurikuler, kokurikuler, ekstrakurikuler, dan perencanaan peningkatan kompetensi sikap. Penjelasan mengenai dua prencanaan tersebut akan dijelaskan sebagai berikut:

\section{Gambaran Umum Kegiatan Belajar Mengajar (KBM) oleh Guru}

Sebelum kegiatan belajar mengajar dimulai guru menyusun perencanan yang akan dilakukan dalam proses belajar mengajar di kelas. Hal ini dilakukan guru untuk memaksimalkan proses belajar mengajar dalam mencapai tujuan pembelajaran dan tercapainya penguatan pendidikan karakter.

Gambaran umum proses belajar mengajar di kelas antaralain:

a. Membuka kegiatan dengan salam dan berdoa di setiap mengawali kegiatan belajar mengajar (wawancara dengan ibu Wara pada tanggal 11 Februari 2020)

b. Sebelum memulai materi, guru memberi penjelasan tujuan pembelajaran. (observasi pada tanggal 3 Februari 2020) 
c. Berdasarkan materi yang telah diberikan kepada siswa, guru memberi pertanyaan untuk memperjelas pemahaman siswa

d. Materi yang telah diberikan kemudian disimpulkan oleh guru

e. Melakukan penilaian dari kegiatan pembelajaran

f. Pembelajaran diakhiri dengan salam dan doa bersama (observasi pada tanggal 3 Februari 2020).

Dalam penerapan kompetensi sikap, guru memilih beberapa pola strategi, yaitu:

a. Pola Keteladanan

Guru perlu menerapkan pola keteladanan agar siswa dapat meniru perilaku yang dilakukan. Perilaku yang ditiru akan diterapkan oleh siswa dalam kehidupan sehari-hari. Menjadi guru favorit agar perilakunya dapat ditiru oleh siswa. Guru memberi teladan dalam hal beribadah, berpakaian, bertutur kata, kedisiplinan, dan kejujuran.

b. Pola Pembiasaan

Dalam kegiatan pendidikan karakter, guru harus menerapkan pembiasan yang baik untuk para siswa. Guru memberikan kebiasaan untuk berperilaku baik seperti disiplin dalam ibadah, berpakaian sesuai aturan, menjaga kebersihan, menerapkan sikap sopan santun. Menegur dan memberikan arahan pada siswa yang tidak sesuai aturan. Guru membiasakan untuk memotivasi siswa agar terbiasa berperilaku baik.

\section{Metode untuk Meningkatkan Karakter Siswa}

Dalam Penguatan karakter pada siswa di SMP Muhammadiyah 4 Sambi dapat dilihat dari kegiatan-kegiatan pembelajaran seperti di bawah ini:

a. Cerita

Guru dalam menjelaskan pentingnya belajar bagi siswa. Cerita dapat memotivasi siswa untuk rajin belajar. Saat guru memberi nasihat kepada siswa agar rajin dalam belajar karena dapat merugikan diri sendiri. Guru memberi motivasi agar siswa belajar dengan rajin supaya saat dewasa naanti ia akan menjadi orang sukses dan dapat meningkatkan derajat keluarganya. (Observasi pada tanggal 28 Januari 2020). Metode cerita bertujuan untuk menyampaikan moral value pada siswa.

b. Papan Slogan

Sekolah menempatkan papan slogan yang berisi kata-kata yang dapat memotivasi siswa agar berperilaku sesuai pesan yang ada pada papan slogan di beberapa dinding sekolah.

c. Piket kelas

Guru selalu mengingatkan siswa untuk memberlakukan jadwal piket yang dikoordinasikan oleh ketua. Tujuan dari piket kelas adalah agar siswa terbiasa menjaga kebersihan lingkungan, baik di dalam kelas maupun di luar kelas.

d. Doa 
Guru membiasakan siswa untuk berdoa pada setiap kegiatan sekolah. Kegiatan ini ditujukan supaya siswa memiliki kepribadian yang baik dan akhlak yang mulia. (Wawancara dengan Ibu Umi pada tanggal 6 Februari 2020).

\section{e. Penghargaan}

Dalam kegiatan siswa bersekolah, untuk meningkatkan semangat belajar siswa perlu dilakukan adanya penghargaan diberikan saat siswa berhasil melakukan sesuatu. Penghargaan akan membuat siswa merasa senang dan termotivasi untuk meningkatkan semnangat belajar siswa. Contoh di SMP Muhammadiyah 4 Sambi yaitu saat kegiatan belajar mengajar, guru selalu memberikan nilai 100 kepada siswa apabila siswa mencatat materi yang disampaikan oleh guru. Kegiatan ini bertujuan agar siswa lebih giat lagi usahanya untuk memperbaiki atau meningkatkan prestasi yang telah dicapainya dan bertujuan memotivasi siswa agar rajin dan semangat untuk mencatat dan memperhatikan guru saat dijelaskan (pengamatan pada tanggal 3 Februari 2020).

f. Hukuman

Saat siswa melakukan tindakan yang salah, guru harus memberikan suatu peringatan. Peringatan yang dapat memberikan pelajaran bagi siswa yaitu hukuman. Hukuman yang diterapkan di SMP Muhammadiyah 4 Sambi kepada siswa yang tidak taat aturan berupa teguran, lari mengelilingi sekolah, push-up, diberikan tugas tambahan. Hukuman tersebut diberikan dengan tujuan agar siswa menaati aturan, menghargai guru, dan tidak mengulangi kesalahan mereka.

Berdasarkan data diatas, strategi pendididikan karakter yang dilakukan oleh guru di SMP Muhammadiyah 4 Sambi sebagai peran fasilitator siswa, terdapat 3 program yaitu:

\section{Kegiatan intrakurikuler}

Kegiatan intrakurikuler yaitu kegiatan terjadwal yang merupakan program utama dalam pendidikan siswa. Di SMP Muhammadiyah 4 sambi, kegiatan intrakurikuler yang dilakukan yaitu KBM (kegiatan belajar mengajar) dan upacara setip hari senin. Serta pembiasaan solat dhuha, yang dilakukan setiap hari selasa sampai sabtu pukul 07:15 pagi sebelum jam KBM dilaksanakan.

\section{Kegiatan kokurikuler}

Kegiatan kokurikuler yaitu kegiatan yang menunjang dan membantu kegiatan intrakurikuler, tujuannya untuk membantu siswa dalam memahami materi belajar yang diajarkan di kegiatan intrakurikuler. Di SMP Muhammadiyah 4 Sambi, kegiatan kokurikuler yang dilakukan adalah les (bimbingan belajar) yang diakukan setiap hari sabtu. Kegiatan bimbingan belajar ini, dilakukan pada siswa kelas 9 yang bertujuan untuk menunjang dan membantu siswa kelas 9 dalam menghadapi UN (Ujian Nasional).

\section{Kegiatan ekstrakurikuler}

Kegiatan ekstrakurikuler yaitu kegiatan yang biasanya dilakukan diluar jam pelajaran, kegiatan ini bertujuan untuk mengembangkan kepribadian, bakat, dan kemampuan di berbagai bidang diluar bidang akademik. Di SMP Muhammadiyah 4 Sambi, kegiatan ekstrakurikuler yanng dilakukan adalah kegiatan BTA (baca tulis Al Qur'an), HW (Hizbul Wathan), dan tapak suci. Kegiatan BTA dilaksanakan setiap hari selasa sampai kamis setelah jam KBM selesai untuk semua kelas. Hizbul wathan dilaksanakan setiap hari Jum'at setelah jam KBM selesai untuk kelas 7 dan 8 . Serta kegiatan Tapak Suci dilaksakan setiap hari sabtu untuk kelas 7 dan 8. 
Peneliti melakukan pengamatan terhadap kultur dan budaya sekolah yang dilakukan oleh guru dalam penguatan pendidikan karakter siswa. Berikut adalah hasil pengamatannya :

\section{Keteladanan}

Keteladanan yang dilakukan oleh guru di SMP Muhammadiyah 4 Sambi adalah berperilaku sopan dan menyenangkan, selalu sabar dalam berbicara dan bertingkah laku. Guru selalu memberikan kritik dan saran yang membangun kepada siswanya, serta memberikan motivasi yang lebih kepada siswanya agar berperilaku baik.

\section{Kerapian}

Kerapian yang diterapkan oleh guru adalah berseragam sesuai dengan aturan tata tertib sekolah. Jika ada siswa yang tidak taat aturan dalam berseragam, guru selalu menegur siswa. Di ruang guru, juga terlihat rapi dan bersih. Guru selalu menegur siswa yang kelasnya tidak bersih dan tidak rapi, sehingga dapat disimpulkan guru sangat menjaga kerapian bagi dirinya dan lingkungan sekolah.

\section{Tanggung jawab}

Dalam sikap tanggung jawab, guru terlihat begitu tanggung jawab dalam melaksanakan tugasnya sebagai pendidik, seperti saat kegiatan belajar mengajar, guru selalu bertanya kepada siswanya tentang kejelasan materi yang sudah diterangkan. Jika ada siswa yang tidak mengerti tentang materi yang diterangkan, guru selalu mengulangi penjelasannya sampai siswanya mengerti materi tersebut.

\section{Ketaatan beribadah}

Dalam ketaatan beribadah, guru selalu melaksanakan ibadah baik wajib maupun sunnah. Dalam beribadah wajib seperti salat dzuhur, guru selalu mengikuti dan menunjukkan ketaatan dan selalu mengingatkan siswanya untuk melaksanakan salat dzuhur dan salat dhuha.

\section{Kepedulian}

Kepedulian terlihat dalam kebersihan lingkungan sekolah, berperilaku, dan berpenampilan sangat peduli baik dengan dirinya sendiri maupun dengan warga sekolah. Jika ada siswa yang bermasalah di sekolah, guru selalu mendekati siswa secara individu agar guru bisa mengetahui penyebabnya. Dan guru juga mengadakan home visit (berkunjung ke rumah siswa) yang bermasalah di sekolah ,serta menjaga hubungan baik dengan orang tua siswa.

Peran dan upaya guru dalam pendidikan berbasis karakter sangat diperlukan, karena siswa perlu bimbingan dari guru untuk mengaplikasikan semua materi pembelajaran dan moral untuk diterapkan dalam kehidupan siswa. Guru perlu mengintegrasikan pendidikan karakter ke dalam pembelajaran pada standar kompetensi yang ada di kurikulum, seperti bersalamn dengan guru ketika di kelas untuk memunculkan rasa hormat pada siswa, penanaman sikap disiplin dan nasionalis. Guru juga harus melakukan kegiatan pembiasaan pada siswa untuk 
mengembangkan karakter dapat dilakukan dengan mengucapkan salam ketika KBM, berdoa, pembiasaan angkat tangan ketika sebelum berbicara, bersalaman ketika bertemu dengan guru. Guru juga harus melakukan integrasi pada pembelajaran tematis dengan mengaitkan segala pembelajaran dengan karakter dan menerapkan di dalam kehidupan sehari-hari sehingga siswa dapat menangkap maksud pembelajaran dengan lebih mendalam. Guru juga harus melakukan pendidikan karakter di segala kegiatan sekolah termasuk di kegiatan ekstrakurikuler.

\section{SIMPULAN}

Berdasarkan hasil penelitian di SMP Muhammadiyah 4 Sambi Boyolali, guru memainkan peran yang sangat penting dalam membangun karakter siswa, karena membangun karakter adalah bagian yang penting dari kinerja pendidikan, karena keberhasilan pendidikan tidak hanya sekedar pencapaian prestasi akademik belaka, tetapi juga merupakan pengembangan karakter dai peserta didik atau siswa. Dalam proses pendidikan karakter, guru harus memahami siswa sesuai karakteristiknya, karena setiap siswa memiliki kepribadian yang berbeda.

\section{DAFTAR PUSTAKA}

Albertus, Doni Koesoema. (2015). Pendidikan Karakter Utuh dan Menyeluruh. Yogyakarta: Kanisius.

Asmani, Jamal Ma'mur. (2011). Buku Panduan Internalisasi Pendidikan Karakter di Sekolah. Jogjakarta: Diva Press.

Badan Penelitian dan Pengembangan Puskur Kemendiknas. (2010). Bahan Pelatihan Pengembangan Pendidikan Budaya dan Karakter Bangsa. Jakarta: Kemendiknas.

Cahyanti, A.E Nur.(2017).Upaya Guru Dalam Penguatan Kompetensi Sikap Siswa Pada Mata Pelajaran Al-Qur'an Hadits di MTS N Surakarta 2 Tahun Pelajaran 2015/2016 [skripsi]. Surakarta(1D): Institut Agama Islam Negeri Surakarta.

Dalimunthe, R.A Abdillah. (2015). Strategi dan Implementasi Pendidikan Karakter di SMP N 9 YOGYAKARTA. Pendidikan Karakter, (1):102-109.

Effendy, Muhadjir. (2016). Arahan Menteri Pendidikan dan Kebudayaan Muhadjir Effendy dalam Pelatihan Pengembangan Kapasitas untuk Penguatan Pendidikan Karakter di Hotel Santika, Jakarta, 27 September 2016. (transkrip rekaman Kemdikbud).

Kemendiknas. (2010). Pembinaan Pendidikan Karakter di Sekolah Menengah Pertama. Jakarta: Departemen Pendidikan Nasional

Undang-Undang Republik Indonesia Nomor 20 Tahun 2003 Tentang Sistem Pendidikan Nasional. 
Ika Indah Pratiwi ${ }^{1}$, Indah Suryati ${ }^{2}$, Aji Nur Cahyo $^{3}$, Felix Indra Setiaputra ${ }^{4}$, Penguatan Pendidikan Karakter

Zairin. (2018). Peran Guru Dalam Pengembangan Karakter Pembelajar. 3(1):1-5.

Hendarman, Ir.M.Sc., Ph.D., dkk. Konsep dan Pedoman Penguatan Pendidikan Karakter. Diakses dari https://paska.kemendikbud.go.id (diakses pada 13 Februari 2020) 